\title{
The Need for Separating the Collections in Academic Libraries
}

\author{
Victoria Frâncu \\ $\mathrm{PhD}$ \\ E-mailv_francu@yahoo.com
}

The concept of collection is of crucial importance for libraries, museums and archives. Defining some clear criteria for documents belonging to one or another of the collections is closely related to the organization of knowledge included in them and has a direct impact on information access. These criteria are necessary more than ever under the existing conditions of digital collections. To this effect, the collection management becomes meaningful to a major extent. The paper will analyze by means of argumentation and examples, the necessity of separating the collections, will present membership criteria of document sets to particular collections and will approach the problem of customizing access to them. The examples provided are taken from the collections of four big Romanian university libraries.

Keywords: library collections; academic libraries; membership criteria; document sets; customized access

\section{Introduction*}

The meaning of collection management, a concept quite different from that of collection development, has to be understood as the activity of adding value, concomitantly with the devaluation of some information bearers, as a result of selection operations (Atkinson, 1998). Preserving in the library only one printed copy of serial publications which, actually, has also a digital version, became in the beginning of 2000's an issue of space but also one of resource effectiveness (Schonfeld 2013). The administration of traditional library collections, particularly the administration of an academic library collections, becomes the more so problematic as the information providing services are conditioned by a digital mentality. In a research report, Roger Schonfeld [1] estimates that the transition from printed to digital documents can be associated with the unsuccessful transition before the year 2000, from printed documents to microforms (Schonfeld 2013). The decisions about the preservation of a document in printed version under the circumstances of its existence in digitized version made the object of an operational research meant to develop a quantitative model concerning the risk management - with an emphasis on environment factors and natural catastrophes, but also with economic implications.

From the above paragraph we can keep in mind the difficulties of managing the library collections under the present conditions of information organization systems and the development of the socalled "digital mentality", mostly obvious in the academic community but, in practice, specific to the entire community of information users. The formal affiliation of documents to one or another of the library collections, the separation of collections according to clear, unambiguous criteria meant to help and promote the value of resources' content are the genuine challenges of today's library systems. The spectacular growth of library resources, the free access to a wide variety of internet resources and the need to adapt the offer to the ever new needs of library users, impose a change of attitude on the level of the academic library collection management.

We shall present in the ongoing a few arguments in favor of separating the library collections, look at some membership criteria for sets of documents to particular collections and tackle the problem of customized access to them. All considerations will be illustrated with examples from real

Revista Română de Biblioteconomie şi Ştiința Informării = Romanian Journal of Library and Information Science ISSN 2559-5490, ISSN-L 1841-1940 • Volume 15 Issue 12019 pp. 16-26 https://doi.org/10.26660/rrbsi.2019.15.1.16

This work is licensed under a Creative Commons Attribution-NonCommercial-NoDerivatives 4.0 International License 
academic library catalogues.

\section{Argument}

The starting point in these considerations was occasioned by a visit to the Oslo University Library late in 1990, a first and decisive opportunity to see the advantages of an automated library at work, with a strong impact on future beliefs and performances.

At that moment, the unified catalogue of the Oslo University Library, also having a national functionality, contained three big subdivisions: SAMBOK for monographs, SAMPER for periodical publications and SAMMUS for musical publications. Additionally, the library was involved in a big image digitization project.

Six years after that, according to a report presented by Øivind Berg (1996) from the Oslo University Library at the ELAG'96 Conference, two image digitization projects were already finalized: The Fridtjof Nansen picture database, from 1992 and a database containing posters and photos showing the German occupation of Norway during the Second World War, from 1994. Another project for digitizing portraits of the Norwegian writer Henrik Ibsen was in progress at the date of Berg's report.

Consequently, the preoccupations of academic libraries to separate their collections according to a set of criteria justified by the optimization of access and an accurate highlighting of their resources is dating from longer than a quarter of a century. Digitization of images was the first step towards establishing digital collections for a variety of resources, organized in collections which are so popular nowadays. These are the reasons which generated the present approach.

\section{The concept of collection - theoretical considerations}

Despite the great number of studies in library and information science devoted to the role of collections in the scientific activity, little attention was awarded to determining the ontological status of collections or to the semantics of the quality of an element belonging to a collection. Collections were coined by theoreticians by terms like: "sets" (Gonçalves et al. 2004), "groups" (Galton 2010), "aggregates" (CIDOC 2010) or "selections" (Lagoze\&Fielding 1998). Beyond the theoretical determination and the necessity of a systematic analysis, according to Wickett et al. (2011), the concept of collection has practical applications. The study of the three authors entitled "Are collections sets?" has as objective the improvement of the search, browse, analysis and extraction of information, in a register which includes metadata about the cultural heritage in the collections as such, but also in their elements.

The academic libraries hold in their custody multidisciplinary deposits of scientific data and their categorization is a necessity determined by their aim and destination. The clear definition of the categories has to take into account, according to the mentioned study, the relationships between the collections properties on different levels. In this context, the question in the title of the study is asked: "Are collections sets" i.e. in the mathematical sense of the word, of their component elements, of their members?

Introducing electronic resources in the library catalogues was a good opportunity for reviewing the way in which the collection development and management were approached. Re-conceptualizing the collections was produced by the inclusion of the digital resources in the libraries. Then again, the descriptions of digital collections are meant to provide contextual information (e. g. about the location, time and connected events, about the provenance, the method of acquisition etc.) to assist research about the elements of the collection. There is no consensual view regarding the attributes of the collection that makes it compatible with various collection concepts already mentioned, such as the electronic resource collection model (Heaney 2000). Such conceptual models, by means of defining the collection properties and the types of relations it can belong to, mediate the 
understanding of the concept and constitute a starting point for terminology and informal definitions (Wickett et al. 2011). The existence of more models and definitions of collection can be the result of certain attributes which make some of them correspond to one concept of collection and others, to another.

The cited study uses the predicate isGatheredInto $(x, y)$ for the relationship established between an element ( $\mathrm{x}$ ) and a collection (y) to which the element belongs. The name of this relationship belongs to the model of collection developed by Heaney (2000) and is used in Dublin Core Collection Application Profile (DCMI, 2007). This model states that a collection is an aggregate of elements (items). The meaning of the term collection is that the resource is described as a group and its parts can be described separately and enable navigation. In the same study, Wickett, Renear şi Furner (2011) use also the predicate Collection $(x)$ to represent the propriety of being a collection. Having these closely related predicates the following informal definitions are given:

Collection: an aggregate of elements

Element (item): a physical or digital resource

to which a remark is added:

\section{an element (item) isGatheredInto one or more Collections}

Starting from this data, 4 possible axioms are formulated for predicate isGatheredInto(xy), as follows:

Axiom 1. If something $y$ has something $x$ gathered into it, then that thing $y$ is a collection.

This axiom is derived from the two definitions previously mentioned.

The relationship defined by isGatheredInto includes also the elements, which can be characterized by the predicate Element $(x)$, hence the second axiom which states:

Axiom 2. If something is gathered into a collection, then it is an element (item).

The converse of the first axiom is:

Axiom 3. If a resource is a collection, then it has something gathered into it.

If this axiom is admitted, then it means that the existence of "empty", or memberless collections is denied.

Axiom 4. A collection can be incorporated as element in another collection, as sub-collection.

The question is whether a collection which belongs to a larger collection can be gathered into that in the same way as the elements of a collection. The answer is depending on the way the curator of that collection considers that a collection integrates those collections in a larger collection, or integrates individual elements of those collections in the bigger collection, depending on the properties or their membership qualities in previous collections (Wickett et al. 2011).

Concluding the four axioms the discussion about collections is reduced to a discussion about is GatheredInto by defining collection $(x)$ on the basis of isGatheredInto $(x, y)$. Hence, according to Wickett, Renear and Furner one plausible definition of a collection is: "we have a collection if and only if there is something gathered into it". The definition is a unified affirmation of Axioms 1 and 3 and has the consequence, derived from Axiom 3, "that there are no empty collections". However, there are situations in which the curator reserves a space, a name, or a preliminary description of a collection which he estimates to create without having, at the moment of its creation, any element in that collection.

This study also presents pros and cons of the assertion that collections are equivalent to sets, one of the conclusions being that sets are commonly associated with the representation of collections in the conceptual models of digital library systems (Lagoze\&Fielding 1998, Gonçalves et al. 2004, 
and Meghini\&Spyratos 2010). For instance, Lagoze\&Fielding (1998) state that a collection is "a set of criteria for selecting resources from the broader information space". In other words, "any set of resources meeting a set of criteria is a collection", the membership being criteria-based. Collections are, therefore, sets of their members. Which holds true, according to the simply formulated set theory saying that for any two things there is a set that has just those two things as members. The authors of the cited study go further saying that this condition is necessary but not sufficient. A set whose members exist cannot become a collection "unless it is treated as such in the appropriate social circumstances". Hence, the quality of a collection is attributed to a set of elements by the role it has in particular social conditions.

In order to illustrate the theoretical approach just mentioned we show the way collections are separated at Bibliothèque Nationale de France (see Fig. 1):

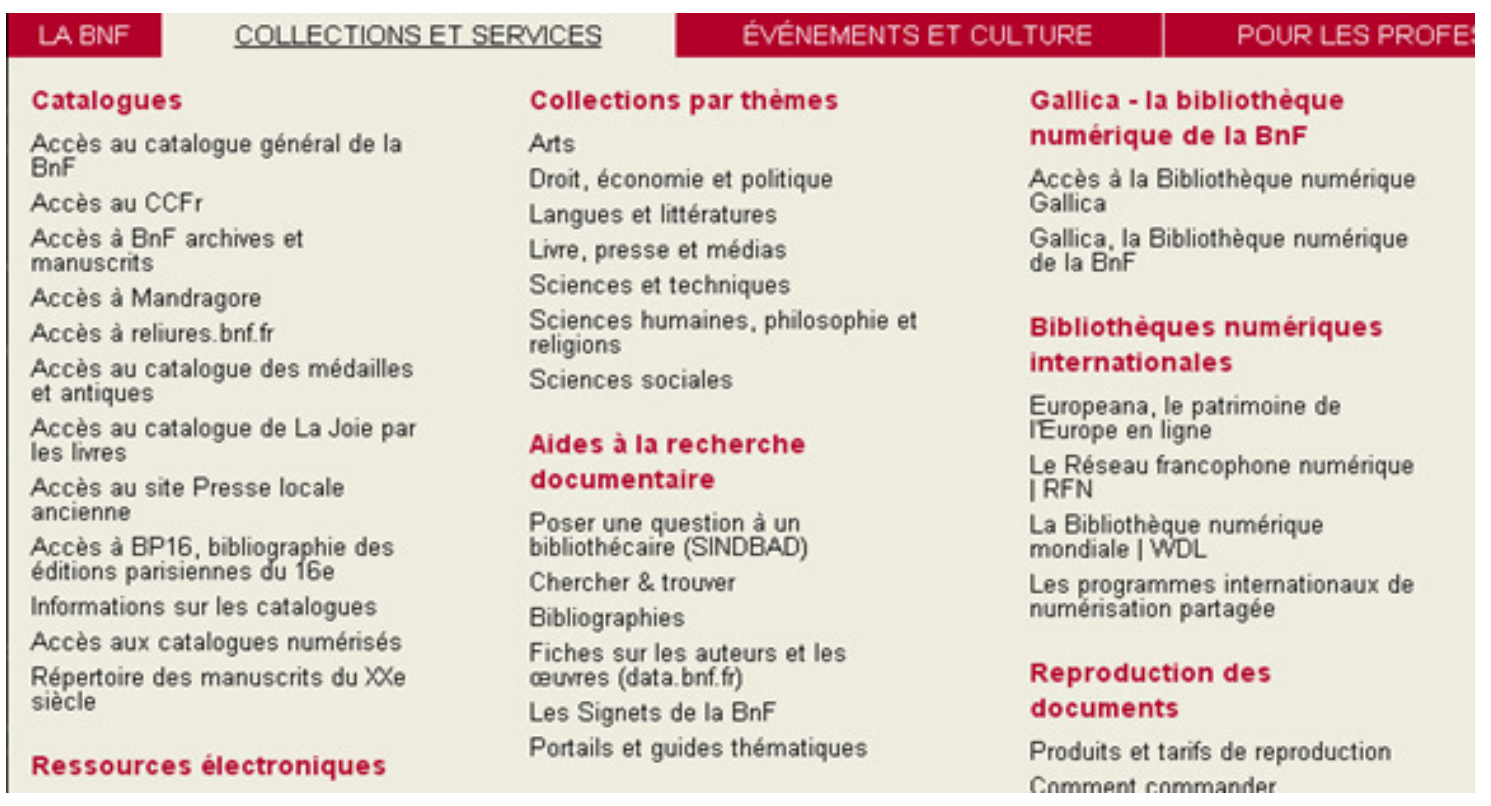

Figure 1. Collections and services at Bibliothèque Nationale de France

\section{On selection criteria and membership of a collection}

Collections are not mere arbitrary aggregates of texts, images, objects, data sets, but they are meant to sustain specific activities and that is why they are designed deliberately to serve a certain purpose (Currall et al. 2004). We shall look in the following sections at the way libraries apply this statement to digital collections.

The selection criteria used at "Lucian Blaga" Central University Library of Cluj (BCU Cluj) in organizing the digital library [2] are: 1) publications which are relevant for the city of Cluj and for Transylvania, 2) publications which are frequently requested by users and 3) documents scanned at the user's demand. The variety of document categories resulting after the application of these criteria expands from manuscripts and old and rare books, to visual documents, periodicals, books and excerpts, works edited by the library and bibliographic lists for university courses. An interesting category for the digital collection of BCU Cluj is Transsilvanica [3], a collection of digital documents which was organized earlier than the above-mentioned ones, and contains manuscripts and other cultural heritage documents selected according to historical and geographic criteria, exclusively concerning Transylvania (see Fig. 2). 


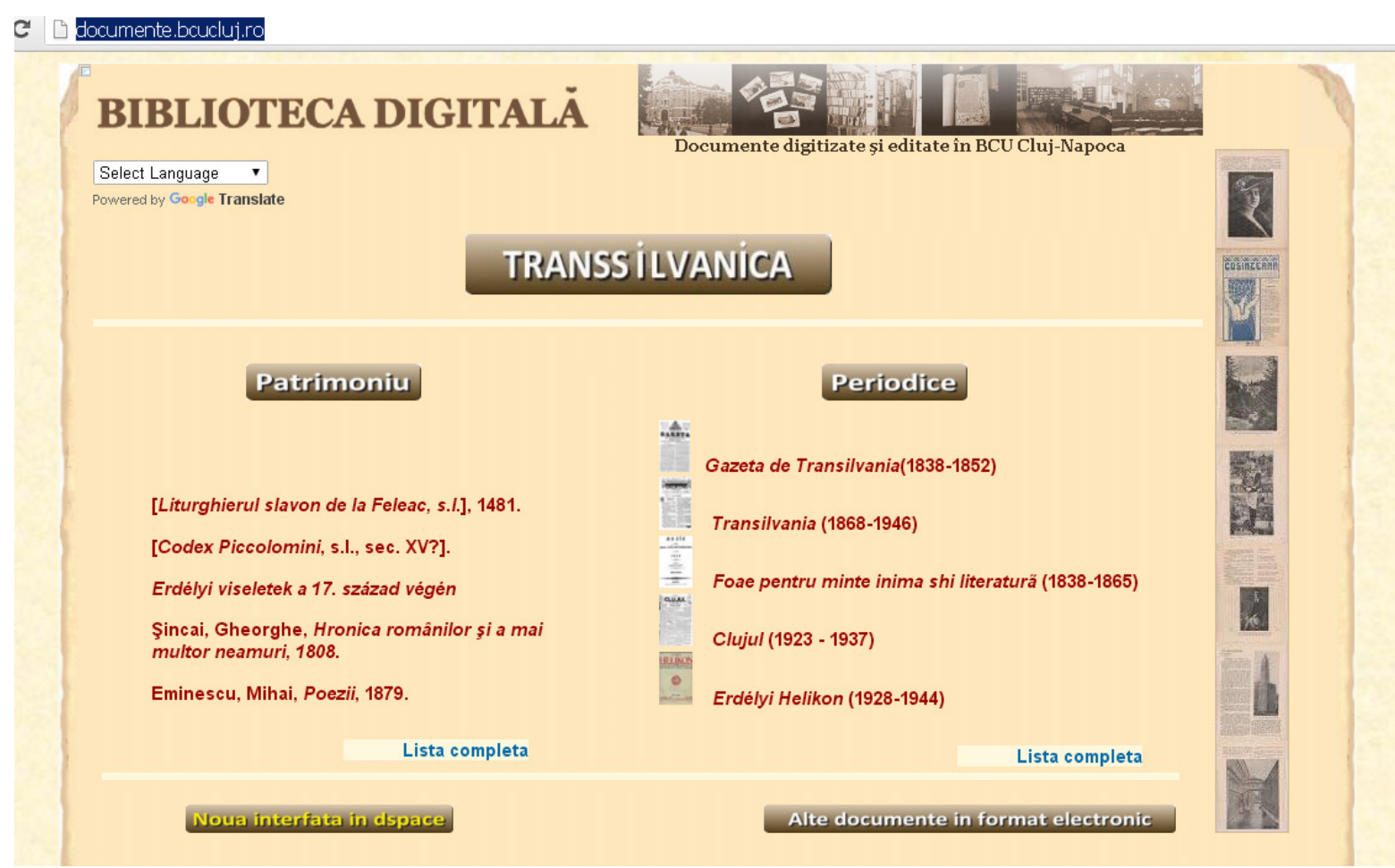

Figure 2. The opening page of Transsilvanica

It goes without saying that apart from the digital library, BCU Cluj has a well-organized general catalogue having well-defined collections. The diversity of collections is the concrete expression of the purpose the library had in structuring them: satisfying the user's information need and an easy access to the content of those collections.

The online catalogue contains beside the digital collection itself, the digitized version of the traditional card catalogue (see Fig. 3 and 4). The latter is subdivided in its turn, into several subcollections, such as: catalogue of special collections, which comprise manuscripts, incunabula, letters and rare books, catalogues for names of printers, typographies and printing centers, catalogues for old books, art albums, maps and atlases, prints, images, photographs/photocopies and ex-libris. To them all, a few catalogues for musical scores are added.
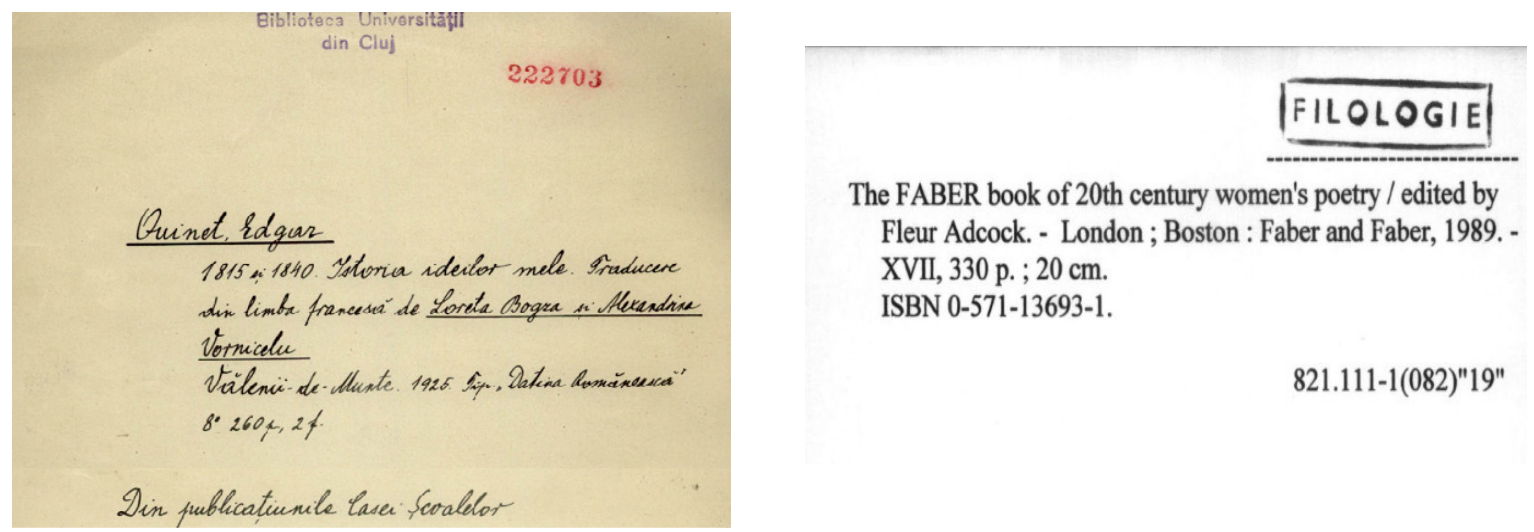

821.111-1(082)"19"

Figure 3. Examples of digitized versions of traditional card catalogue from BCU Cluj 

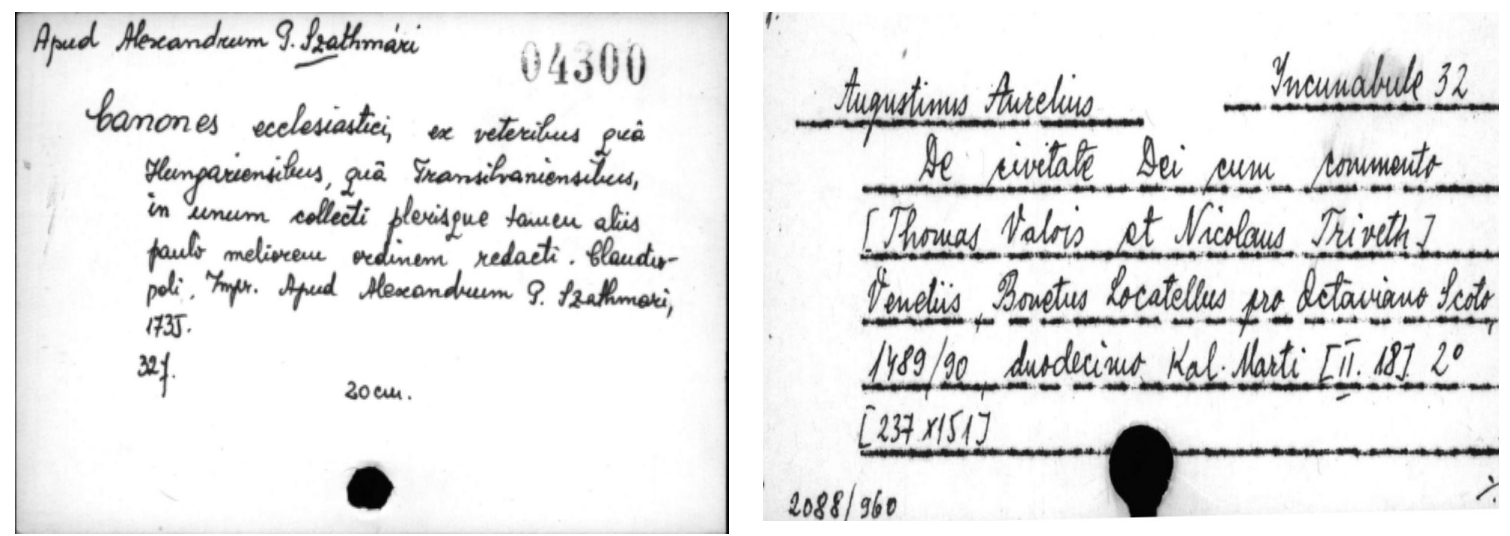

Figure 4. Examples of traditional catalogue cards for names of printers and incunabula from BCU Cluj

At "Carol I" Central University Library of Bucharest (BCU Bucureşti), within the digital platform called Restitutio [4] the following selection criteria were at work: the scientific value of the publication, the document's age, its uncommonness, the exceptional value of the documents for the Romanian and universal cultural heritage, the bibliophile value, the degree of the damage suffered by the documents and, finally, the frequency of the demand for these documents. The document categories resulted after the application of these criteria are: manuscripts and letters, old, rare and bibliophile books, Romanian and foreign current books published after 1880, serial publications, iconographic resources, information and documentation resources published by BCU Bucureşti and documents from the historical archive of BCU Bucureşti.

The last mentioned category is surprising by some inadvertencies, if not disrespect of fundamental rules regarding the author as an entity in the bibliographic description [5]. According to the Romanian law, an author is "the natural person or persons who created the work" [6]. According to the definition in the "Online Dictionary for Library and Information Science", an author is "the person or corporate entity responsible for producing a written work (essay, monograph, novel, play, poem, screenplay, short story, etc.)" [7]. Or, from the descriptions of the digital resources included in the category of documents from the historical archive [8] it results that their authors are librarians from BCU Bucureşti. Actually, those are the authors of contextual metadata concerning those resources. Likewise, some documents were included in the category of information and documentation resources published by BCU Bucureşti never-the-less they were elaborated under completely different auspices than those specified, the rule of uniformity of membership criteria being therefore, ignored.

The necessity of applying consistent selection criteria for the documents and respecting the attributes which provide the membership of different document sets to a certain collection are obvious demands required by the structural accuracy of the digital collection, the visibility of resources within the collection, and finally, the accomplishment of the purpose it was created for: to facilitate the access and satisfy the information need.

Further to the collaboration between "Eugen Todoran" Central University Library of Timişoara (BCU Timişoara) and the Regional Library in Zrenjanin (Serbia) a project called BiblioIdent România resulted, which is a cultural project as component part of the Romanian-Serbian Crossborder Cooperation Program.

The project is briefly described by the library's director, Vasile Docea (2013): "It is about books from various fields, having Banat as subject and books written by authors from this region and works which were printed here. They are as relevant as possible for the multicultural character of the region. The books were printed in German, Hungarian, Romanian and Serbian. Many of them are in Latin". [9] 


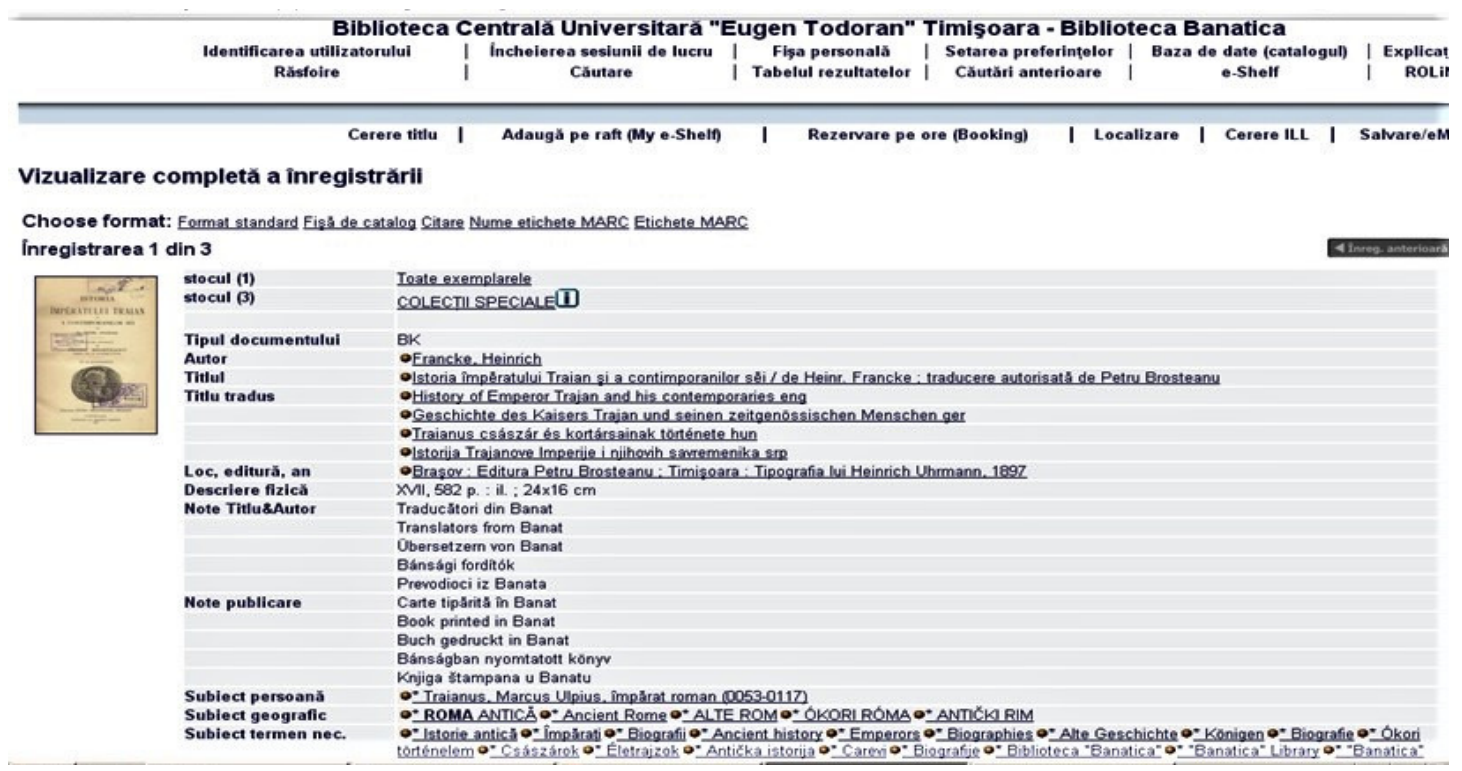

Figure 5. Record belonging to Biblioteca Banatica from BCU Timişoara

Biblioteca Banatica gathers in a digital collection a number of about 1000 titles of documents including: books, leaflets, yearbooks, calendars, atlases, excerpts bound separately and printed music, provided by each partner in the project. A catalogue record for a document belonging to this collection is seen in Fig. 5 and scanned images of the title and contents pages are shown separately in Fig. 6 . They both illustrate the facilities offered by the digital library records to the users of the library.
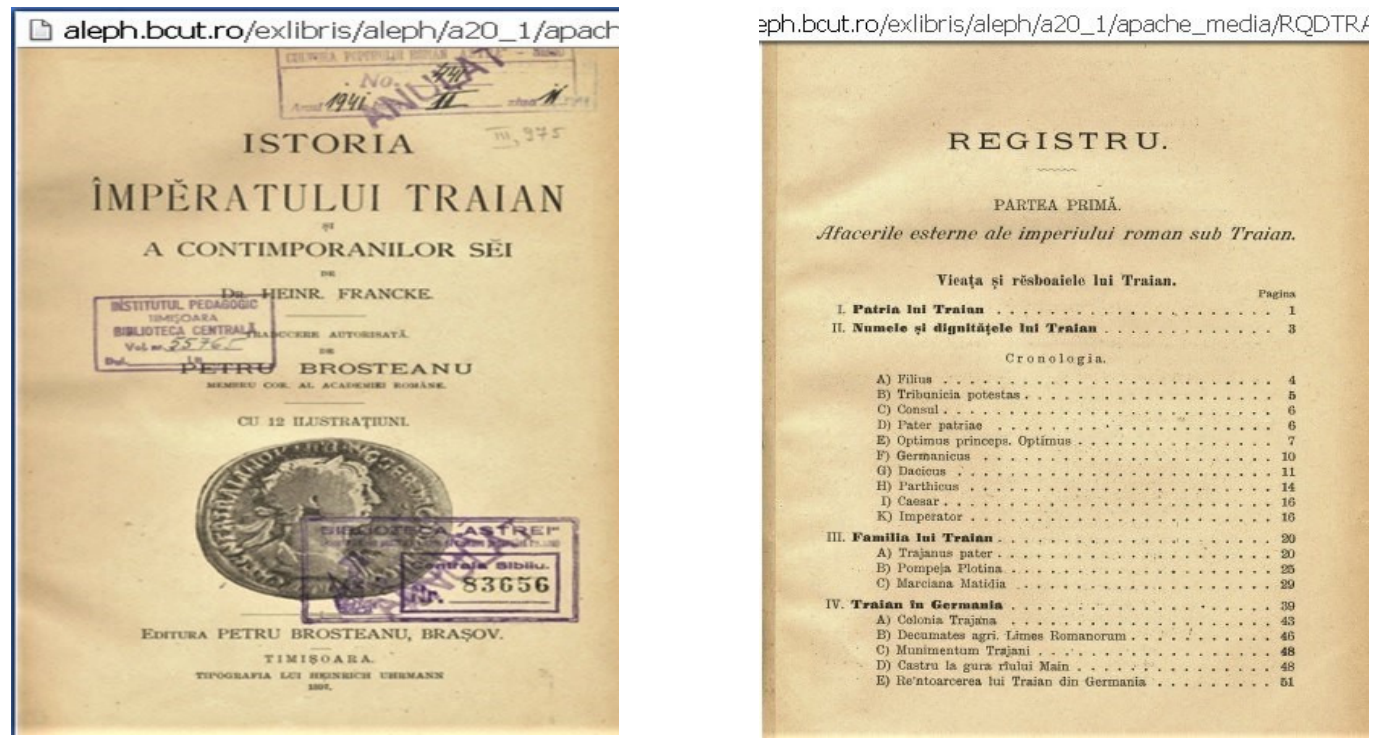

Figure 6. Digital version of the title page and contents page of the document in the record above

As far as the selection of the documents is concerned it was governed by criteria like: the geographic criterion of the printing or publishing place of the document (the geographic names are given in ten languages), the subject criterion (any field of knowledge on condition that it is connected with the historical Banat, together with biographies of personalities in the region) and the criterion of the author or the editor's belonging to Banat's culture. As far as the subjects are concerned, they are oriented to the history, culture and civilization of Banat and deal with the relationship between the communities existing in the historical Banat. 
Another academic library, "Mihai Eminescu" Central University Library of Iaşi (BCU Iaşi) has a special situation. That means, unfortunately, that we cannot speak about a digital collection in itself in their case. At first sight, the online catalogue has only two big parts: 1) the general catalogue and 2) the traditional catalogue. At a closer look, the Aleph 500 catalogue of BCU Iaşi is more wisely structured than other library catalogues, the clarity of its presentation to the user being remarkable. We shall give extra details on the structure of this catalog further on.

According to the year of the library automation, two chronologically separated parts of the library catalogue were organized and additionally subdivided regardless of the information carrier.

The first category comprises:

- Specialized catalogues for books, periodicals, articles from periodical publications, plus a unified catalogue called România, created as a result of a collaboration contract with BCU Bucureşti and BCU Cluj, a catalogue pointed out by each of the partner libraries;

- Separate databases for: books from the $16^{\text {th }}$ century, indexes for magazines such as: "Alma Mater"/"Dialog" and "Universul literar", documents regarding the European Union, eBooks, Bibliotheca Austria, Bibliotheca Germanica.

Digitized catalogue cards dating before 1995, the year of the library automation, were gathered into the second category which contains: books, periodicals and special collections. The bibliographic data relating to these cards were all introduced in Aleph 500, either with complete or summary bibliographic descriptions, so that the information existing in this catalogue can be retrieved (Fig. 7 and 8).

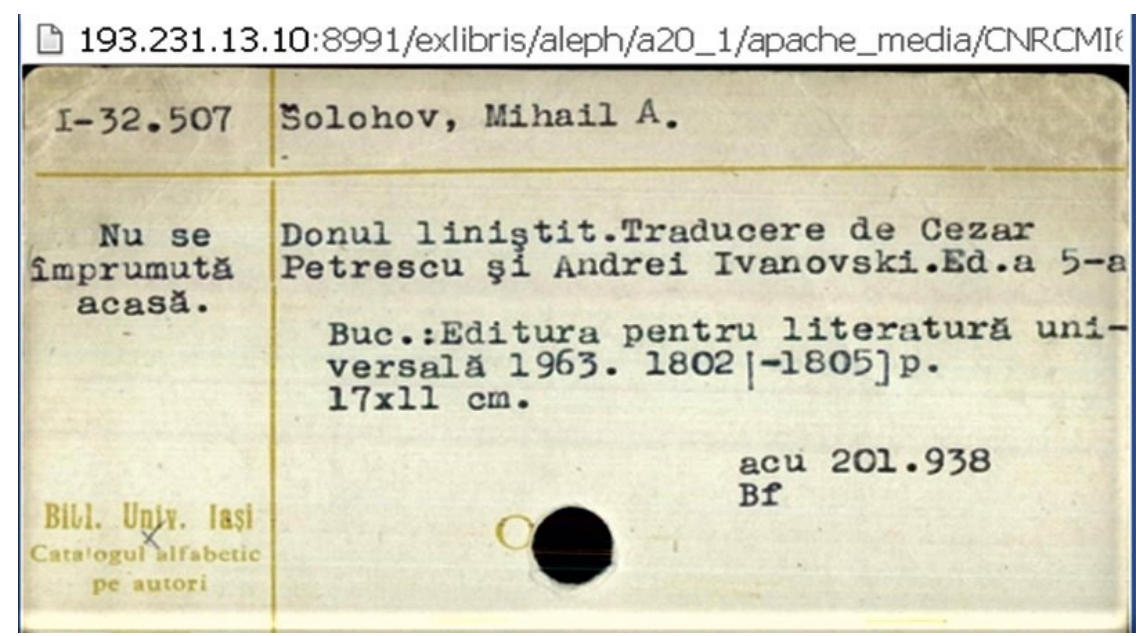

Figure 7. Example of traditional catalogue card in digital version from BCU Iaşi

A complete bibliographic record in the Aleph online catalogue comprises both the standard bibliographic description and the scanned library card as seen in Fig. 8.

\section{General catalogue vs. digital library}

Researchers state that the notion of sets is commonly used to represent collections in models of digital library systems (DCMI 2010). This will not hinder us from using the set properties also when we speak about library collections in general. As long as we have to do with a selection of resources in the information space, based on criteria and having a purpose in certain social circumstances, we can say that we have to do with collections. In the earlier mentioned definition of a collection element we read "a physical or digital resource". Starting from these premises we can talk about the common properties of library collections, irrespective of their nature. 


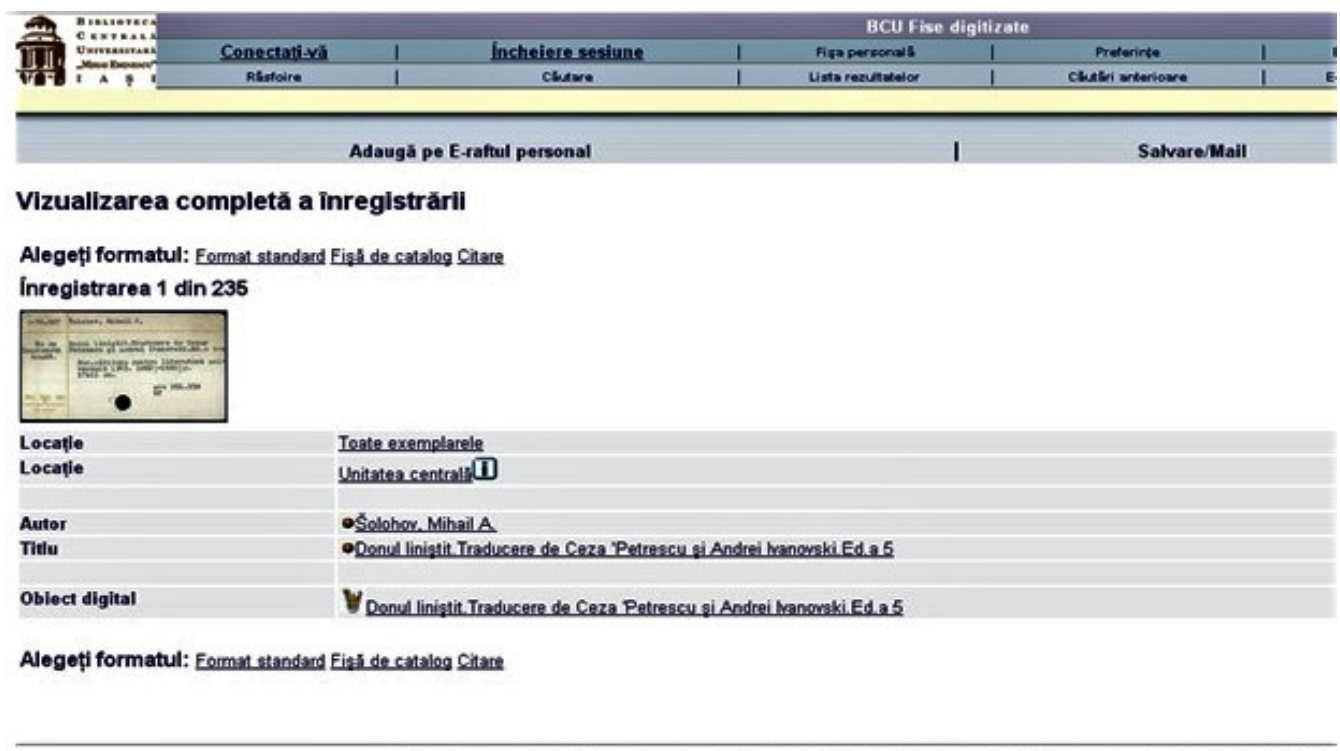

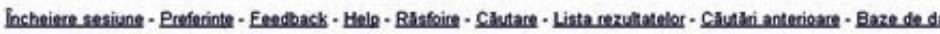

Figure 8. Complete bibliographic record with scanned library card included from BCU Iaşi

The examples given above illustrate the collection management in the four biggest academic libraries in Romania - the central university libraries. There are similarities but also big differences between diverse ways of thinking the collections and, implicitly, of exposing them to the public. It would be interesting to make user studies based on questionnaire and to compare the results obtained for a realist estimation of the catalogue use rate and the satisfaction of the user information need. Until then, however, we can compare the way the collections are reflected and the granularity or specificity of online catalogues.

We firmly believe that the first and most clear distinction that should be operated, no matter whether we consider the physical or digital collections, should be one between the current collection of books and the old and rare book collection. The category of the book as heritage object deserves a separate treatment, having special description rules, a special regime in terms of access and study. Hence, it is understandable why, in three out of the four considered libraries (BCU Cluj, BCU Iaşi, BCU Timişoara) the collections of old books and, in general, the special collections, are separated from the rest of the library collections in the online catalogue.

The recovery and valorization of traditional catalogues by digitization is a resource in itself and brings added value to library catalogues. Digitizing the old working tools - the traditional cards for books and periodical publications, the constitutive elements of the catalogues which enabled the access to the information contained in the library collections proved to be a good practice again, in three out of the four analyzed libraries (BCU Cluj, BCU Iaşi, BCU Timişoara). The information held in these resources is either made available to the user in the form of .pdf document, or, as in the case of BCU Iaşi, integrated in the online catalogue record to the benefit of the user finding additional information along with the advantages offered by the Unimarc format fields.

A careful analysis of the resource characteristics should be at the basis of the selection criteria used in creating digital libraries according to the set of properties of the contributing collections and in keeping with the objective pursued by each library. In most of the cases these criteria are: the frequency of the demand, the age, the scientific value of the documents and their value as cultural heritage objects.

Particular mention has to be made here on the customized access to certain categories of documents. At BCU Iaşi, for example, they make a welcome distinction between particular sets of documents belonging to the library resources. According to these sets, access is differentiated as 
follows:

- BOOK (books), STA (standards), COR (corporative), PAT (patents), AFIS (posters) - are circulated for professors in Rooms nos. 1 and 2, or at home (according to status);

- SER (serials), ZIAR, ANUAR (yearbooks), ALM (calendars, almanacs) - are circulated only in the Periodicals room;

- A (albums), AT (atlases), H (maps), M (printed music), CDR (CD-ROM), DVD, ER (CD+DVD), CSV (video cassettes), CS (audio cassettes), DSC (discs), MF (microfilms), FC (photocopies), IL (photos), CP (postcards), ST (stamps), RV (old Romanian books), CR (rare books), MS (manuscripts), ARH (archive), DOC (documents) are circulated only in "D. Cantemir" Special collections room.

There is a need to make a special remark on the collections of electronic books (eBooks) found in all four analyzed libraries. These have been imported in their online catalogues as standalone databases, having both the bibliographic descriptions and the subjects in English as default values. Since they had all the required properties of a collection accomplished, their import as digital resource discretely delimited, they should not cause problems of access. And yet, instead of being separately emphasized, the eBooks collections were unfortunately incorporated in the general catalogue of the library, their value being thus significantly diminished by scattering the records throughout the general collection.

\section{Conclusion}

In a relatively recent study, Roger Schonfeld (2014) talks about the way the idea that the library should be the initial point in any research endeavor - an idea shared by many library directors turns out to be in conflict with the practice of both teaching staff and students. Since today's library users opt for some other starting points, librarians should invest in ways to bring them back. There is also a good possibility that librarians should re-think their role and formulate a new idea about libraries.

\section{Notes}

* This article has been previously published in Romanian as a conference paper in: Micle, M., Lovasz, A. and Bursașiu, S. (eds.) (2016) Biblioteca fără bariere : Conferința Națională a Asociației Bibliotecarilor din România [Library without borders: The National Conference of Romanian Library Association], ed. 27, 7-9 septembrie 2016, Timișoara: Editura Universității de Vest; București: Editura ABR, 2017, pp. 65-72.

1. "Roger C. Schonfeld is director of Ithaka S+R's Libraries, Scholarly Communication, and Museums program. Roger and the team of methodological experts and analysts that comprise the program conduct research and provide advisory services to drive evidence-based innovation and leadership among libraries, publishers, and museums to foster research, learning, and preservation" (https://sr.ithaka.org/people/roger-c-schonfeld/).

2. Available at: http://dspace.bcucluj.ro/. Accesed 28.08.2016.

3. Available at: http://documente.bcucluj.ro/. Accesed 28.08.2016.

4. Available at http://restitutio.bcub.ro/. Accessed 28.08.2016.

5. This situation was true at the date this paper was written, in august 2016.

6. Lege $n r .8 / 1996$ privind dreptul de autor și drepturile conexe [Law no. 8/1996 on authors rights and related rights], republished in 2018. Available at http://www.legi-internet.ro/legislatie-itc/ drept-de-autor/legea-dreptului-de-autor.html\#c133. Accessed 25.03.2019. 
7. Dictionary definition available at: http://www.abc-clio.com/ODLIS/odlis_A.aspx. Accessed 28.08.2016.

8. Available at http://restitutio.bcub.ro/handle/123456789/221. Accessed 28.08.2016.

9. In Romanian in original: "E vorba de cărți din diferite domenii, care au ca temă Banatul, de cărți scrise de autori din regiune și de lucrări tipărite aici. Cărţile sunt cât se poate de relevante pentru caracterul multicultural al regiunii. Ele au fost tipărite în limbile germană, maghiară, română și sârbă. Multe sunt în latină".

\section{References}

Atkinson, R. (1998) Managing Traditional Materials in an Online Environment: Some Definitions and Distinctions for a Future Collection Management, Library Collections \& Technical Services, 42(1) pp. 7-20, available: https://doi.org/10.5860/lrts.42n1.7.

Berg, Ø. (1996) University of Oslo Library (National Library Services): Progress Report 1995 [online], 20th Library Systems Seminar, Berlin/Germany, available: http://bit.ly/rrbsi12019a.

CIDOC CRM Special Interest Group (2010) Definition of the CIDOC Conceptual Reference Model, version 5.0.2 [online], available: http://bit.ly/rrbsi12019b.

Currall, J., Moss, M. and Stuart, S. (2004) What is a collection?, Archivaria, 58, pp. 131-146, available: https://archivaria.ca/archivar/index.php/archivaria/article/view/12480/13594.

DCMI (2007) Dublin Core Collection Application Profile [online], available: http:// dublincore.org/groups/collections/collection-application-profile/2007-03-09/.

Docea, V. (2013) Fondul "Banatica" în format digital [The "Banatica" collection in digital format], Lecturn 1(4) p. 1, available: http://bit.ly/rrbsi12019d.

Galton, A. (2010) How is a collection related to its members, in Smith, B., Mizoguchi, R. and Nakagawa, S. (eds.), Interdisciplinary Ontology, vol. 3, Tokyo: Keio University, Open Research Center for Logic and Ontology, pp. 9-17.

Gonçalves, M.A., Fox, E.A., Watson, L. and Kipp, N.A. (2004) Streams, Structures, Spaces, Scenarios, Societies (5S): A formal model for digital libraries, ACM Transactions on Information Systems, 22(2) pp. 270-312, available: https://doi.org/10.1145/984321.984325.

Heaney, M. (2000) An Analytical Model of Collections and their Catalogues [online], available: http://www.ukoln.ac.uk/metadata/rslp/model/amcc-v31.pdf.

Lagoze, C. and Fielding, D. (1998) Defining collections in distributed digital libraries, D-Lib magazine [online], 4(11), available: https://doi.org/10.1045/november98-lagoze.

Meghini, C. and Spyratos, N. (2010) Unifying the concept of collection in digital libraries, in Ras, Z.W., Tsay, L.S. (eds.) Advances in Intelligent Information Systems. Studies in Computational Intelligence, vol. 265, Berlin, Heidelberg: Springer, pp. 197-224, available: https:// doi.org/10.1007/978-3-642-05183-8_8.

Schonfeld, R.C. (2013) Preserving Print : Models for Collective Collection Management [online], available: http://bit.ly/rrbsi12019e.

Schonfeld, R.C. (2014) Does Discovery Still Happen in the Library? Roles and Strategies for a Shifting Reality [online], available: http://bit.ly/rrbsi12019f.

Wickett, K.M., Renear, A.H. and Furner, J. (2011) Are collections sets?, in Proceedings of the American Society for Information Science and Technology, 48(1) pp. 1-10, available: https:// doi.org/10.1002/meet.2011.14504801145. 